\title{
CYTOLOGICAL STUDIES OF THE GENUS LINUM, I.
}

BY

\author{
MUNEO KIKUCHI
}

(From the Laboratory of Special Crops, College of Agriculture, Hokkaido Imperial University, Sapporo)

(With Two Plates)

\section{INTRODUCTION.}

The recent cytological knowledge in the plant kingdom ascertains that the numerical relation of chromosomes can exist among species of the same genus.

Genus Linum, to which the most important common flax belongs, involves large numbers of species, affording the interesting materials for cytological studies. There are several references on genetics and cytology of Linaceae. The first report on chromosome number of species belonging to Linum is the paper of TAmmes (1922). She pointed out, from experiments of REYNDERs, Linum usitatissimun $L$. (cultivated flax) and $L$. angustifolium Huds., which is considered as the original form of the former, as having equal number of chromosomes, i. e. 30 in the diploid.

Recently the author also published (1926) his preliminary report on chromosome number of Linaceae, and then Martzenitzina (1927), EMme and Schepeiseva (1927), Vilmorin and Simonet (1927) and Inovye (1929) also worked on the similar topics.

The author, however, had much interest to continue his cytological studies on the present genus, as these workers obtained results somewhat different from him. At the same time the author succeded in getting a new hybrid between some perennial species of Linum. Some out of works hitherto done by him are described in the present paper.

\section{MATERIALS AND METHODS.}

Mcst of the materials were obtained from several Botanical Gardens of Europe and some came from the the Botanical Garden of Hokkaido Imperial University. All of them were grown in the Experimental Plot of the College of Agriculture.

For the count of the haploid chromosome numbers, the meiotic division of pollen mother cells were observed. Flower buds, having diameter of about 1m.m., were selected, their tops were cut off, but the caryxes not removed. They were preliminarily treated by the Carnoy's fluid and then fixed with Flemming's solution. For the observation of somatic chromosomes the young root tip fixed only by CARNoY's fluid 
was used.

The paraffin work was carried on after the tentative schedule of CHAMBERLain. The microtome section was examined in various thickness, but usually the section of about $5 \mu$ gave the most satisfactory result. For the staining the Heidenneis's iron-alum haematoxylin method was exclusively used.

\section{RESUITTS.}

The meiotic division of pollen mother cells was normal as far as the karyological conditions are concerned. The counts of chromcsomes were usually performed in the metaphase and the anaphase. Each chromosome takes the spherical shape in both stages.

The somatic chromosones which were observed in the root tip, were commonly characterized by a long rod, more or less bent in shape and each in almost equal length.

The number of the gametic and somatic chromosomes shows some variation and may be classified as follows:

Group I; $\quad \cdots$...those species having 9 chromsomes in the haploid.

\begin{tabular}{|c|c|c|c|}
\hline Group II; ...... & " & 15 & "I \\
\hline Group III; ...... & $" \prime$ & 18 & " \\
\hline Group IV; ...... & " & $43(?)$ & ' \\
\hline
\end{tabular}

Group I. To this group belong the following species;
a. L. perenne L.
(from Trieste)
b. L. austriacum L.
c. L. altaicum Fisch.
$(" \prime \prime)$
d. L. hologynum Reichb.
( "Delft)
e. L. extraaxillare Kit.
( " Lithuania)
f. L. narbonense L.
" Switzerland)
g. L. sibiricum DC.
(from Amsterdam)
h. L. muelleri Moris.
( " Sutton)
i. L. lewisii Pursh.
(" Edinburgh)
(" Tabore)

All of these species have perennial habit and flowers are colored in deep purplish blue, except $L$. sibiricum, which has two varieties, the white and the blue. Most of these species have the hetersortyled flowers. Seeds are dark brown and very thin. Capsels are dehiscent in the ripened stage.

In the karyological observation 9 paired chromosomes were counted fairly in the diakinesis of the division. In this stage each element showed more or less rod shape but in the metaphase spherical. (Pl. VI Figs. 7-12). 
Group II. In this group are involved the following species:
a. L. usitatissimum I.
(from Sapporo)
b. L. corymbiferum Desf.
c. L. americanum L.
d. L. angustifolium Huds.
(" Tabore)
e. $L$. flavum L.
" Holland)
" Amsterdam)

These species have 15 chromosomes in the haploid and 30 in the diploid (Pl. VI Figs. $1-6)$. L. usilatissimum and $L$. corymbiferum are annual. $L$. angustifolium is described as biennual or perennial but it shows the annual habit in this locality.

The writer has reported in his preliminary paper (1926) that $L$. angustifolium may have 9 chromosomes in the haploid number. The plant previously examined by the writer, however, was not $L$. angustifolium. This error was caused by the misnamed seed which were sent from a foreign Botanical Garden.

Group III. L. alpinum Jacq. is only one species of this group used by the writer. The morphological characters of this species is very similar to those of $L$. perenne and others, belonging to Group I, but cytologically a decided difference exists between them. The present species has twice as many chromosomes as these of the Group I, that is, exactly 18 in the haploid and 36 in the diploid (Pl. VI Figs. $5 \& 6$ ). Simoner reported in his paper that the haploid number of this species is 9 and he wrote to the writer that the material examined by the latter might have been a Japanese tetraploid form. The writer intends to ascertain, whether or not his assumption is right, by a further investigation.

Group IV. L. monogynum Forst. was used as only one species of this group. This plant is also perennial and its morphological characters are somewhat different from others. Its pale purple colored stem is very long and slender, leaf is a little larger than others. Flowers are large and pale yellowish white.

In the karyological study of this species, various numbers of chromosomes were counted. The haploid number of 43 appeared quite frequently, while 86 was detected in somatic cells. As far as the present experiment is concerned, it may be stated that this species has 43 chromosomes at least in the haploid.

\section{CHROMOSOME BEHAVIORS IN A SPECIES BASTARD OF LINUM.}

Gaertaner (1849), Tammes (1911, '13 and '15), Laibach (1925) Bateson (1916), Correns (1912) and Blaringhem (1923 and '26) made some informations on the spe-

1) The writer is much obliged to Miss. T. Tammes, who kindly sent him seeds of this species. The writer also offers his hearty thanks to Prof. A. W. Henry, Alberta University, Canada, for seeds cordially sent him. 
cies crosses of Linum from the standpoint of genetics, though no cytological meaning was considered.

In the summer of 1926 the writer examined the cross of $L$. alpinum $\times L$. perenne. As above mentioned, these species are perennial plants and the chromosome numbers are just $18+9$ in the haploid. Some seeds were raised in the autumn of 1926, and the cytological investigation was carried on about them.

Fig. 13 (Pl. VII)shows the somatic metaphase in the young root tip, counting positively 27 chromosomes. 'This number is obviously the sum of the parental haploids, but as their size was almost same, it was quite difficult to distinguish chromosomes of the paternal plant from those of the maternal. A few of these hybrid plants bloomed in 1927, and more of them in 1928.

In the pollen mother cells of these $F_{1}$ plant, no abnormal figures were observed in the prophase and in the metaphase of the heterotypic division, but in the heterotypic anaphase some irregularities were detected. In the Figs. 14-16 (Pl. VII) we can see clearly that 9 bivalent chromosomes are massing at each pole after the division, while the other 9, presumably univalents, lagging on the spindle and moving to either pole at random in the progress of the division. In such way some variations of the chromosome numbers must occur in the heterotypic division, settling themselves at each pole. The examination of many preparations proved that various numbers of chromosomes were counted in the homeotypic metaphase and anaphase of the pollen mother cells. Figs. $17-20(\mathrm{Pl}$. VII) show divisions to 13 and 14,12 and 15 or 11 and 16 chromosomes in these stages.

Thus one may be able to surmise that in the gametic division of the $F_{1}$ plant the variation of the chromosome number may occur as follows:

\begin{tabular}{|c|c|c|}
\hline $\begin{array}{l}\text { Daughter halves } \\
\text { of bivalents }\end{array}$ & Univalents & $\begin{array}{l}\text { Daughter halves } \\
\text { of bivalents }\end{array}$ \\
\hline
\end{tabular}

9

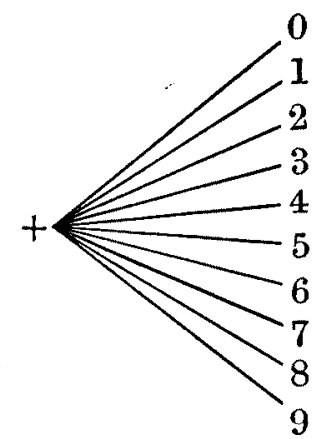

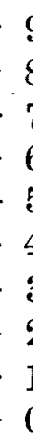

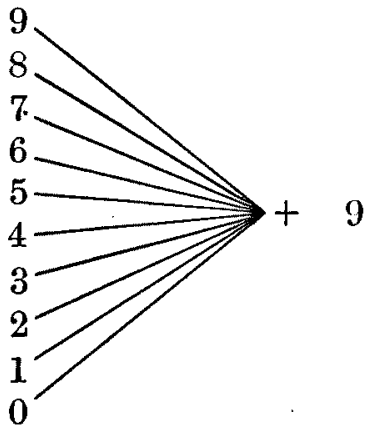

$=$

27

$\mathrm{F}_{1}$ plants were crossed inter se in both natural and artificial ways, and a few seeds $\left(\mathrm{F}_{2}\right)$ were obtained in the former case. On these seeds many cytological experiments were made and several numbers of somatic chromosomes were counted as follows 
in the young root tip. (Pl. VII Figs. 22-27).

\begin{tabular}{c|c}
\hline Plant number. & somatic chromosomez. \\
\hline$(\mathrm{P} \times$ A) No. 6 & 20 \\
$(\mathrm{P} \times$ A) No. 14 & 28 \\
$(\mathrm{P} \times$ A A 8 & 34 \\
\hline
\end{tabular}

The writer expects to continue the present studies in more detail.

\section{DISCUSSION.}

Many reports were published regarding the difference in the chromosome number among species of Linum. The first paper was made by TAMmes (1922). She insists that $L$. usitatissimum and $L$. angustifolium have 30 chromosomes in the somatic cells. Martzenitzina (1927) states in his paper that species of Linum can be grouped into 5 sections according to the number, dimension and shape of the chromosome. He counted chromosomes in the meristem of the rootlets or in the meristem of the stem; his results may be summarized as follows;

\begin{tabular}{c|c|l}
\hline section & \multicolumn{1}{|c}{$\begin{array}{c}\text { diploid number } \\
\text { of chromosomes }\end{array}$} & \multicolumn{1}{c}{ species } \\
\hline I & 18 & $\begin{array}{l}\text { L. austriacum. } \\
\text { L. tenuifolium. } \\
\text { L. corymbiferum. } \\
\text { L. punctatum. } \\
\text { L. perenne. }\end{array}$ \\
\hline II & 16 & L. grandiflorum. \\
\hline III & 32 & $\begin{array}{l}\text { L. usitatissimum. } \\
\text { L. angustifolium. }\end{array}$ \\
\hline IV & 30 (possibly 32) & L. flavum. \\
\hline V & over 57 & L. catharticum. \\
\hline
\end{tabular}

From these results he concludes that the genus Linum is karyologically not homogeneous and species belonging to this genus differ from each other not only in the number, but also in the size and shape of chromosome. And from the forgoing results he said that the cytological data agreed best with the arrangement of species in the synopsis of Ascherson and Graebner (1914). For the diploid number of 32 in the third group he described as follows: The divergence between his data and those of REYNDERs ( $L$. usitatissimum and $L$. angustifolium, $2 \mathrm{x}=30$ chromosomes each) may be explained by an accidental segmentation or by the fact that REYNDERs treated flax races differing karyologically from his ones. The last mentioned explanation is made in view of the analogy with experiments in rye, in which KrHara (1924), Goror (1924) and Bellivg (1925) found 2 races differing in chromosomes of the somatic cell. 
The writer also carefully observed the number of chromosomes in $L$. usitatissimum and $L$. angustifolium and always found that their chromosome numbers were $2 \mathrm{x}$ $=30$ and $x=15$.

EmME and Schepel.Jeva (1927) reported their studies on L. usitatissimum and especilly on $L$. usitatissimum $I_{\text {. }}$ var. crepitane. They observed 2 cases; in one case they found 30 as the somatic chromosome number but in many others 32 . Such a fact was already found by Goron (1924) in Secale cereale and by EMME (1927) in Secale fragile

VILMORIN and SimoneT (1927) made the cytological works on the genus Linum, counting $8,9,10,14$ and 15 as haploid chromosome numbers in various species of Linum.

INovye (1929) informed in his latest report that he observed 16 and 9 as haploid chromosome numbers of $L$. usitatissimum and $L$. perenne respectively, while he counted previously 15 as the haploid number of $L$. usitatissimum. Thus he assumes two forms in $L$. usitatissimum having 15 and 16 haploid numbers respectively.

So far as these studies are concerned, we find decided differences in chromosome numbers of species belonging to Linum, and also some divergence in resultt of these investigations. The writer's results are mostly consistent with the others', but in some cases are not. As to $L$. usitatissimum and $L$. angustifolium, observations of TAMmes, Vilmorin and Simonet agree with the writer's. But Martzenitzina reports $2 \mathrm{x}=$ 32 in above species, EMme and SchepelJEva desribe two cases for $L$. usitatissimum, i.e. $\mathrm{x}=15$ or $16,2 \mathrm{x}=30$ or 32 , and INouY reports for $L$. perenne the same chromcsome number as found by the writer, while for $L$. usitalissimum the same as reported by EMme and SchepelJEva. From these investigations they conclude that the divergence of the chromosome number can exist in L. usitatissimum just as detected in rye, but thus far the writer has never found such a case. In $L$. corymbiferum Martzentizina counts 18 as the diploid number, while the writer 15 in the haploid and 30 in the diploid. The writer doubts whether or not the materialused by both workers are genetically the same. Further cytological investigations may be able to note more divergence of chromosome numbers in the genus Linum. In the following table are indicated the results obtained by the writer and others. 


\begin{tabular}{|c|c|c|c|c|c|c|c|c|}
\hline \multirow{2}{*}{ Name of } & \multirow{2}{*}{$\frac{\text { TAMMES }}{2 x}$} & \multirow{2}{*}{$\frac{\text { Martzenitzina }}{2 \mathrm{x}}$} & \multicolumn{2}{|c|}{$\begin{array}{l}\text { EMME AND } \\
\text { SCHFPELLJE- } \\
\text { VA }\end{array}$} & \multirow{2}{*}{$\frac{v_{\text {ILMORIN AND }}^{\text {SIMONET }}}{x}$} & \multirow{2}{*}{$\frac{\text { I }_{\text {NOUYE }}}{x}$} & \multicolumn{2}{|c|}{ KIKणCHI } \\
\hline & & & $x$ & $2 x$ & & & $\mathbf{x}$ & $2 x$ \\
\hline L. perenne & - & 18 & - & - & 9 & $\mathbf{9}$ & $\mathbf{9}$ & 18 \\
\hline L. austriacum & - & 18 & - & - & - & - & 9 & 18 \\
\hline L. altaicum & - & - & - & - & - & - & 9 & 18 \\
\hline L. hologymum & - & - & - & - & - & - & 9 & 18 \\
\hline L. extraaxillare & - & - & - & - & - & - & 9 & 18 \\
\hline L. narbonense & - & - & - & - & - & - & 9 & 18 \\
\hline L. sibiricum & - & - & - & - & 1 & - & 9 & 18 \\
\hline L. muelleri & - & - & - & - & - & - & 9 & 18 \\
\hline L. lewisii & - & - & - & - & - & - & 9 & 18 \\
\hline L. salsoboides . & - & - & - & - & 9 & - & - & - \\
\hline L. strictum & - & - & - & - & 9 & - & - & - \\
\hline L. tenuifolium & - & 18 & - & - & 9 & - & - & - \\
\hline L. punctatum & - & 18 & - & - & - & - & - & - \\
\hline I. maritimum & - & - & - & - & 10 & - & - & - \\
\hline L. campanulatum & - & - & - & - & 14 & - & - & - \\
\hline L. nervosum & - & - & - & - & 15 & - & - & - \\
\hline L. flavum & - & $\begin{array}{c}30 \\
\text { (possibly } 32 \text { ) }\end{array}$ & - & - & - & - & 15 & 30 \\
\hline L. americanum & - & (pussiony 32$)$ & - & - & - & - & 15 & 30 \\
\hline L. corymbiferum & - & 18 & - & $\overline{100}$ & - & - & 15 & 30 \\
\hline L. usitatiss mum & 30 & 32 & $\left\{\begin{array}{l}15 \\
16\end{array}\right.$ & $\left\{\begin{array}{l}30 \\
32\end{array}\right.$ & 15 & 16 & 15 & 30 \\
\hline L. angusiffolium & 30 & 32 & - & - & 15 & - & 15 & 30 \\
\hline L. alpinum & - & - & - & - & 9 & - & 18 & 36 \\
\hline L. catharticum & - & over 57 & - & - & 8 & - & - & - \\
\hline L. grandiflorum & - & 16 & - & - & 8 & - & - & - \\
\hline I. hirsutum & - & - & - & - & 8 & - & - & - \\
\hline I. monogynum & - & - & - & - & - & - & & \\
\hline
\end{tabular}

In many species hybrids appearances of the irregular behavior in the heterotypic division are described by several authors. ROSENBERQ (1909) reported that in the hybrid between two species of Drosera, having 10 and 20 haploid chromosomes respectively, 10 bivalent and 10 univalent chromsomes were observed in the diakinesis. $\mathrm{He}$ also found the similar fact in a hybrid of Hieracium auricula $(x=9) \times H$. auranticaum $(\mathrm{x}=18)$. In the hybrid of Triticum polonicum $(\mathrm{x}=14) \times T$. spelta $(\mathrm{x}=21)$ Kinara (1919) detected 14 bivalent and 7 univalent chromosomes in the heterotypic metaphase. Moreover, Gates (1909) fonnd the same behavior of chromosomes in the hybrid between two species of Oenothera, YasuI (1921) in Papaver, SAx (1922) in Triticum, TaEckHolm $(1920,1922)$ in Rosa and Ichusma (1926) in Fragaria hybrids.

In species hybrids in Linum many experiments also were made by several authors. KoELREUTER (1787) described on the hybrid of L. usitatissimum $\times$ L. narbonense and of the reciprocal crossing, but by CoRrens (1921) and LAIBACH. (1925) it was proved that his hybrid was $L$. usitatissimum $\times L$. angustifolium. 
Later the crossing experiments of $L$. usitatissimum $\times$ L. narbonense were tried by Tammes (1915̃), Bateson (1916), Correns (1921) and Laibach (1925), but none of them brought any result. GAERTNER (1848) tested to make crosses of $L$. usitatissimum with $L$. maritimum, $I$. flavum and $L$. perenne, but there was no result. In crossing $L$. usitatissimum with $L$. perenne, $L$. austriacum, $L$. grandiflorum and $L$. flavum, TAMmEs $(1915,1918)$ noticed the formation of slightly developed seeds, which failed to germinate. TAMmes $(1911,1913)$, LaIBach (1925) and Blaringhem (1923, 1926) investigated genetically in the hybrid of $L$. usitatissimum $\times L$. angustifolium.

This cross was very easily produced, and it is only one species hybrid hitherto known in the genus Linum.

GaRgas and Smith (1915-16) examined vast numbers of crosses between $L$. peirenne, austriacum, narbonense, monogynum,grandiflorum, flavum, arboreum and marilimum. Out of these various crosses, however, only two of $L$. monogynum $\times L$. narbonense and $L$. monogynum $\times L$. arboreum gave some seeds. They stated that these $F_{I}$ plants were closely related to the mother plant $(L$. monogynum), but further descriptions of their descendants are not yet published.

As far as the writer's memory goes, he has never seen any cytolological paper regarding species hybrid in Linum. So he feels a great interest in continuing his studies to confirm how his hybrid and its descendants behave as regards the chromosome number, and if any of them can be bred true, it may bring a much more interesting result.

\section{SUMMARY}

The results obtained from the above mentioned investigations may be summarized as follows:

1. According to the chromosome number, species of Linum used by the writer may be classified into four groups having 9, 15, 18 and 43 (?) in haploid numbers respectively.

2. The difference in the size and shape of chromosome was not noted in both gametic and somatic cells.

3. L. usitatissimum did not reveal any variation in the chromosome number, showing always $x=15$ and $2 x=20$

4. In the hybrid of $L$. perenne $\times \quad L$. alpinum, chromosome number in the somatic cell of $F_{1}$ is the sum of gametic ones of the parental plants, i. e. $9+18=27$.

5. In the heterotypic division of pollen mother cells of $F_{2}$ plant, there is seen the irregular chromosome behavior, where 9 lagging univalent chromosomes separate at random to each pole, and in the homeo-typic metaphase various numbers of chromosomes from 9 to 18 were counted.

6. In the karyological observation of F, plants, 20,28 and 34 somatic chromosome numbers were detected in young root tip cells.

In conclusion the writer wishes to express his heartiest thanks to Mr. K. YoSFInDA, who carried out most of the laboratory technics. He is also greatly indebted to Prof K. Akemine and Mr. Hirata for their valuable advices. 


\section{References Cited}

1. Ascherson, P. und P. Gratbner. (1914) : Synopsis der mittel-europïischen Flora. 84-85 Lieferung. 75.225.

2. BeLling, I. (1925) : Fractures of chromosomes in rye. J. Hered., XVI, 360-361.

3. Blaringhem, L. (1023): Etudes sur la sèlection des Lines. I. Caractéres morpholigiques utilisés pour la séparation et le contrôle des lignées pures. Rev. Bot. Appl. et Agri. Colon.T. III, $1-25$.

4. " (1921) : Recherches sur les hybrides due Lin. (Linum usila'issimum L.) C. r. Acad. Bci. CLXXIII, 320-331.

5. " (1926): Methodes et resultats dans l'hybridation des Lins a fibres. C. $\mathbf{r}$. Acad. Sci., CLXXXII, 278-279,

6. Chamberlain, A. M. (1920): Methods in Plant Histology. The Univ. of Chicago Press.

7. Correns, C. (1921) : Zahlen- und Gewichts-verhältnisse bei einigen heterostylen Pflanzen. Biol. Zentralbl. XLI, 97-109.

S. EMme.H. u, H. ScntprelJeva (1927) : Veriuch einer karyologischen Artanalyse von $L$. usilatissimum I. Bull. Appl. Bot. Gen. \& Pl.-Br., XVII, 253-264.

9. Gates, R, R (1909): The behavior of the chromosomes in Oenothcra lata $\times$ Oe. gigas. Bot. Gaz., XIVIII, 170-199.

10, GoroH, K. (1924): Ueber die Chromosomenzahl von Sesale cereale L. Bot. Mag. (Tokyo), XXXVIII, 135.151.

11. Inoure, G. (1929): Studies on the Development of Chromosomes in Linum. Proc. Crop Sci. Japan, NO. 3, 3956.

12. KinarA, H. (1910): Ueber cytologische Studien bei einigen Getreidearten. I. Spezies-Basterde des weizens und Weizenroggen-Basterde. Bot. Mag. (Tokyo), XXXIII, 17-38.

13. "I (1924): Cytologische und genetische Studien bei wichtigen Getreidearten mit beson derer Rücksicht auf das Verhalten der Chromosomen und die Sterilitït in den Bastarden. Menoirs of the College of Science. (Kyoto), Ser. B, No. 1.

14. KIKvCHI, M. (1926): Studiez on the difference of chromosome numbers in Linum species. J. Soc. Agr. \& For. (Sapporo), No. 81, 26-37.

15. Laibach, F, (1924): Frucht- und Samenbildung bei heterostylen Linum-Arten. Z. Ind. Abst. u. Vererb., XXXIII, 267-268.

16. Martzentzina, K.K. (1927): The chromosomes of some species of the genus Linum. Bull. Appl. Bot. Gen. and PI.- Br., XVII, 253-264.

17. Rosenberg, O. (1909): Cytologische und morphologische Studien an Drosera longifolia $\times$ D. rotundifolia. Kgl. Svensk. Vet. Handl.,XLIII, 3-64.

18. TAMMEs, T. (1915): Die genotypische Zusammensetzung einiger Varietäten derselben Art und ihr genetsicher Zusammenhang. Rec. Trav. Bot. Neerl., XII, 271-273.

10. " (1922): Genetic analysis, schemes of cooperation and multiple allelomorphs of Linum usitatissimum. Genet., XII, 19-46.

20. " (1923): Das genotypische Verhältnis zwischen dem wilden Linum angustifolium und dem Kulturlein, Linum usitatissimum. Genetica, V. 61-76.

21. " (1928): The Genetics of the Genus Linum. Bibliographia Genetica, IV, I-36.

22. Tobler,F. (1923): Der Flachs als Faser- und Oelpflanze. Berlin.

23. VARGAS Erre, J. \& G. SMirh. (1915'-16): Some notes on the Linaceae. The cross pollination of flax. J. Genet., V, 189. (16)

24. Vinmorin et Mare Simonet. (1927): Nombre dez chromosomes dans les genres Lobelia, Linum et chez quelques autres espéces Végetales. $C$. 


\section{Explanations of Plates}

All figures were observed under ZEIss compensation ocular 18 and apochromatic objective $1,5 \mathrm{~mm}$. (1/12), and were drawn by the aid of ABBE's camera lucida.

Fig. 1. 15 gametic chromosomes at the heterotypic metaphase in L. usitalissimum.

Fig. 2. 30 somatic chromosomes of the same.

Fig. 3. 15 gametic chromosomes at the heterotypic metaphase of $L$. americanum.

Fig. 4. 30 somatic chromosomes of the same.

Fig. 5. Homoeotypic metaphase of $L$. alpinum, showing 18 gametic chromosomes.

Fig. 6. Root tip cell of the same, showing 36 somatic chromosomes.

Fig. 7. 9 chromosumes at the homoeotypic metaphase in $L$. perenne.

Fig. 8. 9 chromosomes at the homoeotypic metaphase in $L$. sibiricum.

Fig. 9. Heterotypic metaphase of $L$. austriacum, showing 9 gametic chromosomes.

Fig. 10. Root tip cell of $L$. perenne, showing 18 somatic chrumosomes.

Fig. 11. 18 somatic chromosomes in the root tip cell of $L$. austriacum.

Fig. 12. 18 somatic chromosomes in the root tip cell of $L$. sibiricum.

Fig. 13. 27 somatic chromosomes in the root tip cell of the hybrid $L$. perenne $\times$ L. alpinum.

Fig. 14-16 The early anaphase of the hetetrotypic division in the pollen mother cell of the same hybrid, showing 9 bivalent chromosomes aggregating at the pole and 9 univalents, which lagged in the spindle, separating at random to each pole.

Fig. 17. The late metaphase of the homoeotypic division in the pollen mother cell of the same hybrid, showing 12 chromosomes exactly.

Fig. 18-20. Homoeotypic metaphases in pollen mother cells of the same hybrid, showing 12 and 15,13 and 14 , and 11 and 16 respectively.

Fig. 21. The tetrad formation of the $F_{1}$ plant.

Fig. 22-23. 34 somatic chromosomes in $F_{2}$ individual.

Fig. 26-27. 20 " " " "

\section{Linum 屬 の細胞學的研觉（第一報） \\ 菊地武直夫}

摘 要

Linum 屬には多数の㪙(Species)を含で居るが、是等に就て細胞學的研究は他の植物に此較 して最近に於て進められたもので. Tamaes (1922), Kikuch (1926), Martzenitzina (1927), Emme 及 SChepeideva (1927), Vilmorin 及 Simonet (1927) 及 Inouye (1929) 亿低つ

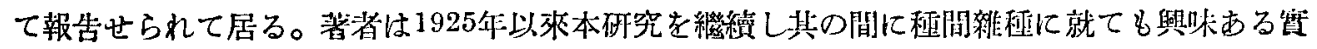
驗を進めつ」ある。其の大略を摘鉨すれば。

1. MARTZENITZINA は彼の研究に用ひた Linum 屬の程を染色體數の上から5澵に分類し

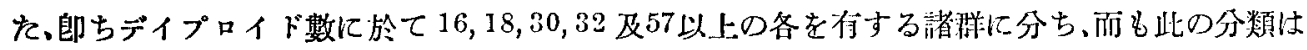
AschERSON 及 GRAEBNER の分類と相通する所ある老䢑ぺて居る。著老は其の研究材料を深 色體のハプロイド數により次の如く分類した。 

第一類
第二 類
第三 類
（ $x=9$ 有するしの
( $x=15$ なっ有するの)
$(x=18$ 有する
第四類
$(x=43(?)$ 有有する 6の)

L. alpinum.

L. monogynum.
L. perenne
L. usitatissimum.
L. corymbijerum.
L. altaicum.
L. americanum.
L. hologynum.
L. angustifolium.
L. extraaxillare
L. flavum.
L. narbonense.
L. sibiricum.
L. muelleri.
L. lewissi.

2. MARTZENITZINA は種により染色體の數、形狀及大小を異にすると迹へて居るが著者 の研究では数的考異は明であるが他の差異は認め得ない。

3. L.usitatissimum 及 L. anguslifolium に就ては多くの研究者に上り次の如く染色體数の異 なるるのを報告されて居る。

\begin{tabular}{lcccc} 
& \multicolumn{2}{c}{ L. usitatissimum. } & L. angustifolium. \\
TAMMES & $x$ & $2 x$ & $x$ & $2 x$ \\
KIKUCHI & & 30 & & 30 \\
MARTZENITZINA & 15 & 30 & 15 & 30 \\
EMME 及 SChEPELJEVA & $\left\{\begin{array}{l}15 \\
16\end{array}\right.$ & 32 & & 32 \\
VILMORIN 及 SIMONET & 15 & & & \\
INOUYE & 15 & & 15 & \\
16 & & &
\end{tabular}

Emme 及 SchepelJeva \& INOUYE は L.usitatissimum k於て $\mathrm{x}=15$ 及 $\mathrm{x}=16$ の二和 類ある事を派へて居るが、著者は此の種に於て15以外のハプロイド僌は数へ得す。

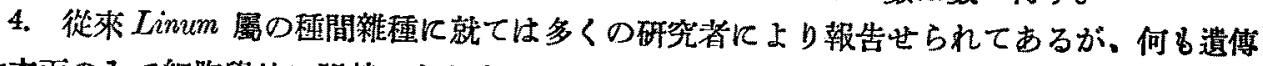
學的方面のみで細胞學的に記械せらたものはない。著者は1926年多年生なる L. perenne（x= 9) と L. alpinum $(x=18)$ との交配により得た雜種に就き研究し其の根端細胞に於て 27 の深 色體を数へた。此の數俚明に雨親のハプロイド數の和である。

5.上記の雜種の F 1 亿於ける花粉母緗胞に異型核分裂に於て染色體の不規則なる行動を 朋に認めた。即ち同分裂の後期に於て 9 の二價染出體が网極に進んだ後、赤道板附近に散在す

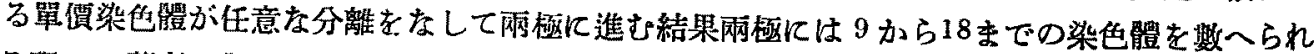
る理で、著者の觀察に於ても 11 と16,12と15,13と14の三通りの分れ方が第二分裂の中期に於て 認められた。此の類の現像は他の種間雜程に於てを見られた現像で、こてに新に一侧を見出し た理でする。

6. 此の種事の $F_{2}$ に於て根端細胞に於ける染色體數を覞察し、20,28及34を讀み得た。之

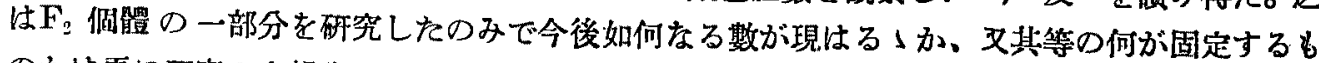
のかは更に砸究の上報告する㘼である。 
JAPANESE JOURNAL OF GENETICS, VOL. IV.

PLATE VI
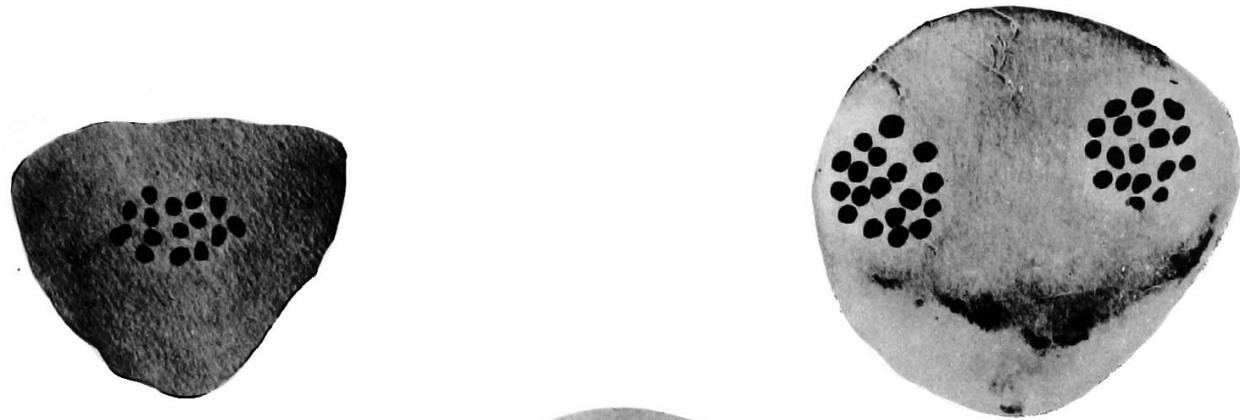

Fig. 1.
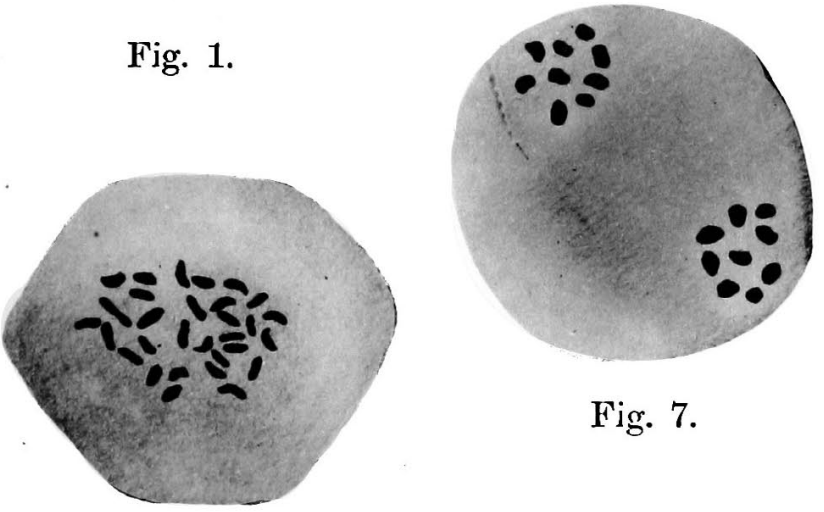

Fig. 7.

Fig. 5 .

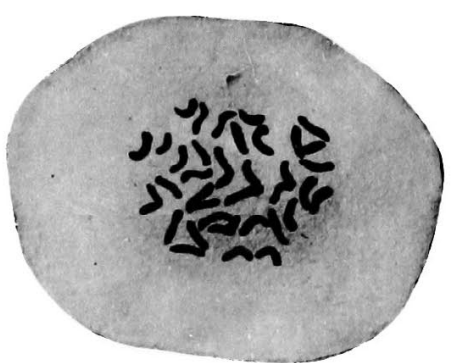

Fig. 2.

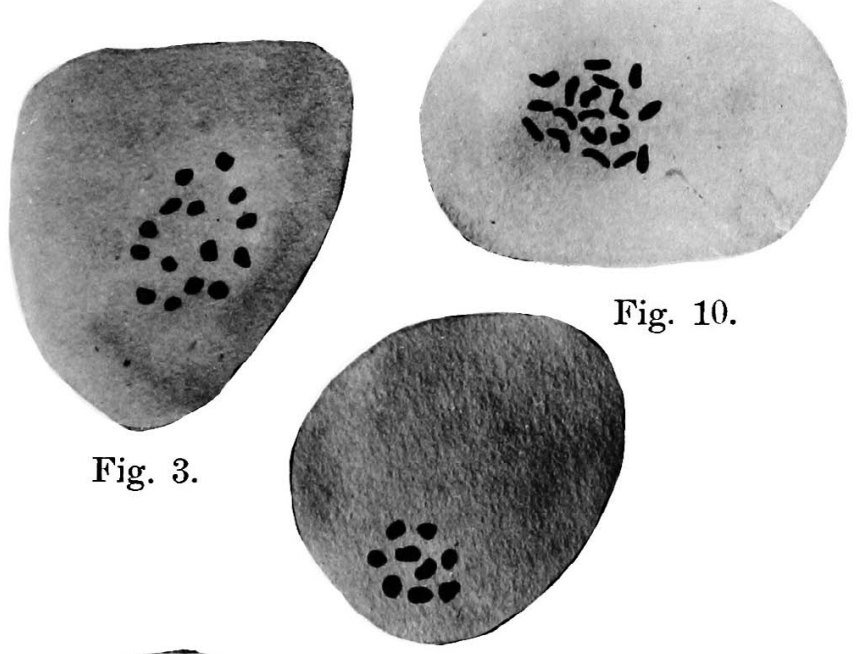

Fig. 6.

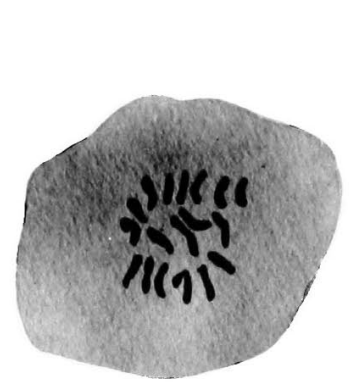

Fig. 11.

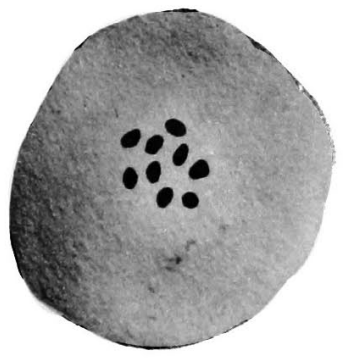

Fig. 9.
Fig. 8.

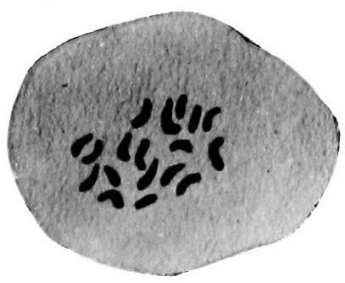

Fig. 12.

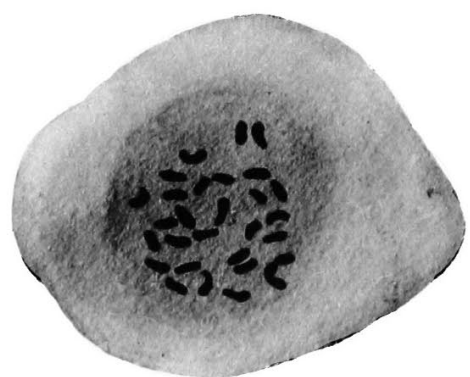

Fig. 4. 
JAPANESE JOURNAL OF GENETICS, VOL. IV.

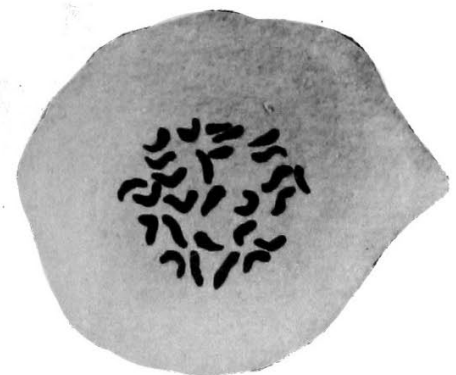

Fig. 13.

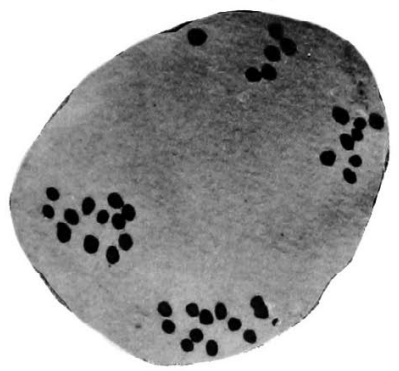

Fig. 17.

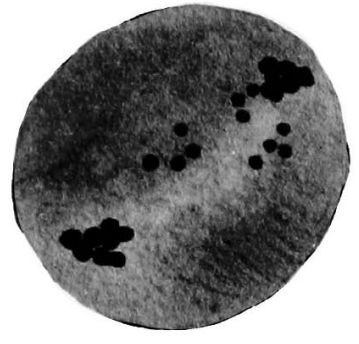

Fig. 14.

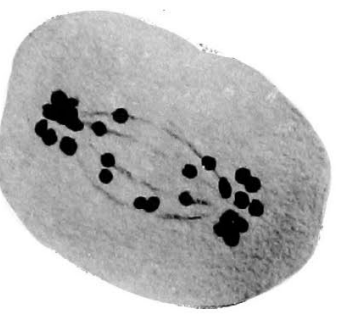

Fig. 16 .

PLATE VII

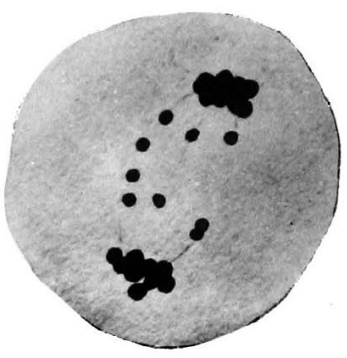

Fig. 15 .

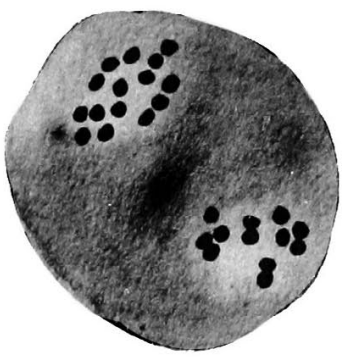

Fig. 18.

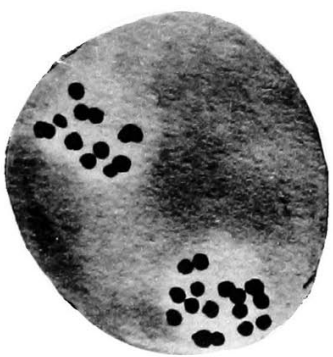

Fig. 20.

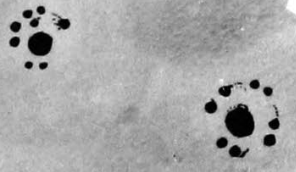

Fig. 22 .

Fig. 19.

$\therefore$

Fig. 21

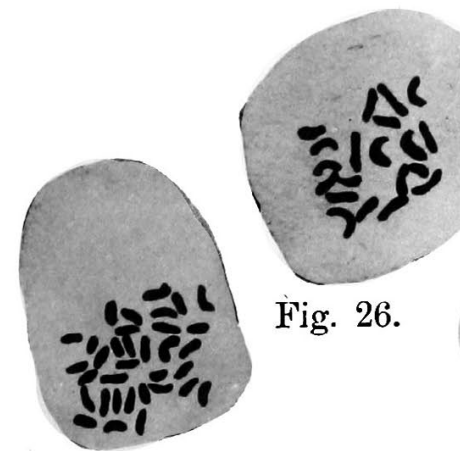

Fig. 23.
Fig. 24.

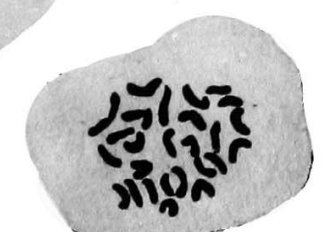

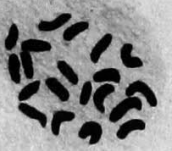

Fig. 27.

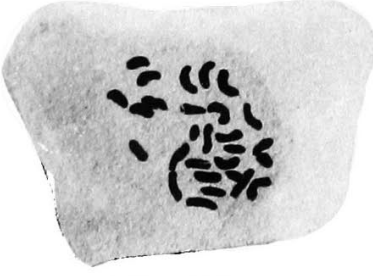

Fig. 25. 